\title{
Analisis tingkat kepuasan pasien rawat inap pengguna Jaminan Kesehatan Nasional di Rumah Sakit Bhayangkara Tingkat II Medan
}

\author{
Institut Kesehatan Helvetia \\ *Korespondensi: danarmichaelhalawa@gmail.com \\ DOI: 10.34012/jpms.v2i2.1456 \\ (C) 2020 JPMS. All rights reserved
}

Firman Yanus Halawa, Thomson Parluhutan Nadapdap, Mangatas Silaen

\begin{abstract}
Abstrak
Pembangunan kesehatan sebagai salah satu upaya pembangunan nasional yang dilaksanakan oleh semua komponen bangsa Indonesia. Survey BPJS Kesehatan tahun 2014 menunjukkan kepuasan peserta BPJS Kesehatan yang datang ke RS pemerintah (80\%) lebih rendah dari RS swasta (83\%). Dimensi tangible serta responsiveness merupakan titik lemah dari RS pemerintah jika dibandingkan RS swasta yang pada akhirnya mempengaruhi tingkat kepuasan. Penelitian ini bertujuan untuk menganalisis tingkat kepuasan pasien rawat inap pengguna Jaminan Kesehatan Nasional berdasarkan dimensi tangibles, reliability, responsiveness, assurance dan empathy di RS Bhayangkara Tingkat II Medan. Jenis penelitian ini adalah kuantitatif survey analitik dengan pendekatan crosssectional. Sampel berjumlah 100 orang pasien yang diambil dengan menggunakan teknik purposive sampling. Data dikumpulkan melalui penyebaran kuesioner, lalu dianalisis menggunakan uji Chisquare dan uji regresi logistik. Hasil uji menunjukkan hubungan yang signifikan antara variabel tangibles, reliability, responsiveness, assurance dan empathy dengan tingkat kepuasan pasien. Hasil analisis multivariat dengan logistic regression menunjukkan bahwa variabel reliability merupakan yang paling dominan dalam memengaruhi kepuasan pasien di ruang rawat inap Rumah Sakit Bhayangkara Tingkat II Medan (Exp $(B)=101.776)$. Dapat disimpulkan bahwa dimensi yang paling domi-nan memengaruhi tingkat kepuasan pasien di ruang rawat inap rumah sakit Bhayangkara Tingkat II Medan adalah reliability. Untuk menyusun strategi peningkatan pelayanan di Rumah Sakit Bhayangkara Tingkat II Medan perlu dipertimbangkan strategi yang difokuskan pada kepuasan pelanggan.
\end{abstract}

Kata kunci: Kepuasan pasien, Jaminan Kesehatan Nasional

\begin{abstract}
Health development is one of the national development efforts carried out by all components of the Indonesian nation. BPJS Kesehatan's survey on 2014 showed that the satisfaction of BPJS Kesehatan participants who came to general hospitals (80\%) was lower than private hospitals (83\%). Tangible dimensions and responsiveness are the weak points of general hospitals when compared to private hospitals which ultimately affect the level of satisfaction. This study aims to analyze the level of satisfaction of inpatient users of National Health Insurance based on the dimensions of tangibles, reliability, responsiveness, assurance and empathy at Bhayangkara Medan Hospital. This type of research is a quantitative analytic survey with a cross-sectional approach. A sample of 100 patients were taken using purposive sampling technique. Data were collected through distributing questionnaires, then analyzed using the Chi-square test and logistic regression test. The test results showed a significant relationship between tangibles, reliability, responsiveness, assurance and empathy variables with the level of patient satisfaction. The results of multivariate analysis with logistic regression showed that the variable reliability was the most dominant in influencing patient satisfaction in the inpatient room of Bhayangkara Medan Hospital (Exp $(B)=101,776)$. It can be concluded that the most dominant dimension influencing the level of patient satisfaction in the inpatient room of the Bhayangkara Medan Hospital is reliability. To develop a service improvement strategy at the Bhayangkara Medan Hospital, it is necessary to consider a strategy that is focused on customer satisfaction.
\end{abstract}

Keywords: Patient satisfaction, National Health Insurance 


\section{Pendahuluan}

Pelayanan kesehatan adalah segala upaya yang diselenggarakan secara sendiri atau secara bersama-sama dalam suatu organisasi untuk memelihara dan meningkatkan kesehatan, mencegah dan menyembuhkan penyakit serta memulihkan kesehatan perorangan, keluarga, kelompok ataupun masyarakat. ${ }^{1}$

Salah satu upaya pemerintah dalam peningkatan kesehatan masyarakat dengan mendirikan rumah sakit di setiap daerah. Rumah sakit adalah bagian integral dari keseluruhan sistem pelayanan kesehatan. Kementerian Kesehatan telah menggariskan bahwa rumah sakit umum mempunyai tugas melaksanakan upaya kesehatan secara berdaya guna dan berhasil guna dengan mengutamakan upaya penyembuhan dan pemulihan yang dilaksanakan secara serasi dan terpadu dengan upaya peningkatan dan pencegahan kesehatan yang bermutu dan terjangkau oleh masyarakat dalam rangka melaksanakan upaya rujukan. ${ }^{2}$

Pertumbuhan rumah sakit saat ini menunjukkan perkembangan yang pesat. Tahun 2001 jumlah rumah sakit pemerintah di Indonesia 598 unit dan akhir tahun 2008 mencapai 655 unit. Sedangkan rumah sakit swasta tahun 2001 berjumlah 580 unit dan akhir tahun 2008 mencapai 699 unit. Hal ini menimbulkan persaingan rumah sakit semakin ketat. Timbulnya persaingan menyebabkan berbagai rumah sakit berupaya meningkatkan mutu pelayanan kesehatan. Salah satunya adalah dengan meningkatkan profesionalisme petugas kesehatan untuk meningkatkan kepuasan pasien. ${ }^{3}$

Kepuasan pasien atau peserta dari asuransi merupakan salah satu faktor yang dapat digunakan sebagai acuan dalam menentukan keberhasilan progam pelayanan. Hal ini berarti bahwa kualitas yang baik dari suatu layanan bukan berdasarkan pada persepsi penyedia jasa, tapi berdasarkan pada persepsi konsumen, karena konsumenlah yang menikmati pelayanan yang diberikan oleh perusahaan. ${ }^{4}$ Tingkat kepuasan yang tinggi dapat membuat pelanggan menjadi lebih setia dan dapat menunjukkan performa perusahaan yang baik sehingga melakukan analisis tingkat kepuasan pasien menjadi hal yang penting untuk dilakukan demi tercapainya pelayanan kesehatan yang berorientasi kepada pasien. ${ }^{5}$

Seiring meningkatkan mutu pelayanan, maka biaya pelayanan kesehatan juga semakin tinggi. Tingginya biaya kesehatan semakin menyulitkan masyarakat untuk memperoleh layanan kesehatan. Salah satu metode yang dapat digunakan dalam meringankan beban pembiayaan kesehatan dengan menggunakan asuransi. Upaya telah dilakukan pemerintah dalam memberikan jaminan kesehatan untuk masyarakat seperti adanya Jaminan Kesehatan Nasional (JKN).

Menurut Khariza (2015), target yang ingin dicapai melalui pelaksanaan program Jaminan Kesehatan di Rumah Sakit adalah pencapaian kepuasan pasien yang dapat memberikan pengaruh positif bagi masyarakat, pencapaian kesembuhan pasien bisa maksimal dengan tolak ukur pasien tidak kembali ke Rumah Sakit. ${ }^{6}$

Hasil survei yang dilakukan oleh BPJS pada tahun 2014, menunjukkan bahwa indeks nasional kepuasan peserta adalah $81 \%$, sedangkan indeks nasional kepuasan faskes sebesar $75 \%$. Jika dibandingkan dengan sasaran pokok JKN 2014 yang ingin mencapai indeks kepuasan peserta sebesar $75 \%$ dan faskes sebesar $65 \%$, hasil survei ini menunjukkan bahwa BPJS Kesehatan di tahun pertama masa karyanya telah berhasil melampaui sasaran tersebut. Di tingkat Fasilitas Kesehatan Tingkat Pertama (FKTP) dan Fasilitas Kesehatan Tingkat Lanjut (FKTL), indeks kepuasan peserta tidak berbeda signifikan, yaitu $80 \%$ di tingkat FKTP dan $82 \%$ di tingkat FKTL. Hasil survey BPJS Kesehatan mencatat, pada 2017 indeks kepuasan peserta sebanyak $79,5 \%$ dan untuk indeks kepuasan faskes sebesar $89,5 \%$. Sedangkan bila dibandingkan dengan indeks pada 2016, untuk kepuasan peserta sebesar $78,6 \%$ dan faskes 76,2\%.7 Hasil penelitian Fadillah (2017) di Rumah Sakit Umum Daerah Langsa Sumatera Utara pada pasien peserta BPJS menunjukkan angka tertinggi adalah kurang puas sebesar $55,7 \%$ (44 orang), puas sebesar 40,5\% (32 orang) dan terendah adalah tidak puas $3.8 \%$ (3 orang). ${ }^{8}$

Penelitian serupa oleh Pertiwi (2016) di Rumah Sakit Umum Daerah Kota Surakarta tentang perbedaan kualitas pelayanan pada pasien BPJS dan pasien umum menunjukkan perbedaan yang signifikan antara pasien BPJS dengan umum, hal ini terlihat pada nilai mean kepuasan pasien umum lebih tinggi $(20,50)$ 
dibanding pasien BPJS $(17,19) .{ }^{9}$

Rumah Sakit Bhayangkara Tingkat II Medan adalah salah satu rumah sakit Tingkat II yang dimiliki Polri di samping di wilayah Bandung, Surabaya dan Makasar yang merupakan salah satu provider pelayanan kesehatan program Jaminan Kesehatan Nasional di Kota Medan. Ditinjau dari kategori organisasi rumah sakit setara kelas B, yaitu rumah sakit yang mempunyai pelayanan dengan minimal sebelas spesialistik dan subspesialistik. ${ }^{10}$

Rumah Sakit Bhayangkara Tingkat ॥ Medan berupaya memberikan pelayanan kesehatan yang semaksimal mungkin sesuai dengan fasilitas dan sarana yang tersedia, memiliki 105 tempat tidur, SDM 229 orang, pelayanan medis meliputi pelayanan spesialis rawat jalan, pelayanan rawat inap dan pelayanan instalasi untuk menunjang pelayanan medis. ${ }^{11}$

Survei awal yang dilakukan peneliti pada tanggal 25 Juni 2018 berdasarkan data rekam medik Rumah Sakit Bhayangkara Tingkat II Medan, pada bulan Januari sampai bulan Juni menunjukkan nilai rata-rata Bed Occupancy Rate (BOR) yakni 41,16\%. BOR Rumah Sakit Bhayangkara masih rendah sesuai dengan nilai parameter BOR yang ideal menurut Depkes RI (2005) yaitu $60-80 \% .^{12}$

Berdasarkan hasil survei awal dari data rekam medik Rumah Sakit Bhayangkara Tingkat II Medan, didapatkan data kunjungan pasien umum dan pasien pengguna jaminan kesehatan nasional di 3 ruangan yaitu ruang Anggrek (Kelas I, II), Flamboyan (Anak dan Obgyn), dan Mawar (Kelas III) bahwa jumlah pasien umum ruang rawat inap dari bulan Januari-Juni 2018 adalah 153 orang, sedangkan pasien pengguna Jaminan Kesehatan Nasional (JKN) adalah 639 orang.

Jumlah pasien umum dan pengguna JKN didapatkan perbedaan yang sangat besar. Menurut pihak manajemen Rumah Sakit Bhayangkara Tingkat II Medan, diperkirakan pada bulan-bulan berikutnya akan terus meningkat. Ini akan menjadi perhatian bagi manajemen rumah sakit untuk mempersiapkan SDM dan fasilitas yang baik terutama untuk pasien Jaminan Kesehatan Nasional. ${ }^{12}$

Data kotak saran tahun 2016 terdapat 124 surat, di mana 77 (62,0\%) surat menyatakan keluhan mereka dengan alasan petugas kurang ramah dalam memberikan penjelasan menge- nai persyaratan BPJS yang rumit, kemudian waktu petugas memeriksa hanya sebentar dan dokter yang terlambat visite tanpa adanya pemberitahuan atau penjelasan dari perawat. ${ }^{12}$

Dari hasil data dan wawancara yang dilakukan peneliti pada tanggal 25 Juni 2018 kepada 25 pasien pengguna JKN yang dirawat inap di Rumah Sakit Bhayangkara Tingkat II Medan yakni 15 orang laki-laki dan 10 orang perempuan menanyakan tentang pelayanan rumah sakit khususnya pelayanan dokter, pelayanan keperawatan serta kenyamanan pasien. Hasil dari wawancara menyatakan bahwa 16 orang mengatakan belum memuaskan, 9 orang mengatakan cukup memuaskan. Dilihat dari aspek manajemen di Rumah Sakit Bhayangkara Tingkat II Medan masih ditemui permasalahan laporan perkembangan asuhan keperawatan pasien yang tidak lengkap dan masih banyaknya keluhan pasien terhadap ketersediaan obat.

Rasa nyaman saat menjalani pengobatan di rumah sakit menjadi bagian penting bagi pasien yang dapat mempercepat kesembuhan. Kenyamanan seperti mendapat informasi dan komunikasi yang cukup serta keramahan petugas ikut memberi andil bagi kesembuhan pasien. Orang sakit itu bukan hanya butuh pengobatan, melainkan juga perhatian dan mendapatkan informasi memadai. Oleh karena itu, petugas medis harus selalu memberi pelayanan yang baik. Pasien tidak hanya mementingkan hasil akhir saja, berupa kesembuhan dirinya atau keluarga semata, tetapi mereka sudah menilai apa yang mereka lihat dan rasakan saat dirawat inap pada pasien.

Semakin tingginya tuntutan masyarakat atas fasilitas kesehatan yang berkualitas dan terjangkau, maka perlu untuk rumah sakit memperhatikan dimensi tangibles, reliability, responsiveness, assurance, dan emphaty. Wawancara juga telah dilakukan kepada petugas rumah sakit diketahui bahwa belum terdapat tindak lanjut terhadap keluhan pasien tersebut dan belum dilakukannya survei langsung, sehingga mereka ingin bekerjasama dengan peneliti untuk survei kepuasan pasien. Penelitian bertujuan untuk menganalisis kepuasan pasien rawat inap pengguna Jaminan Kesehatan Nasional di Rumah Sakit Bhayangkara Tingkat II Medan. 


\section{Metode Penelitian}

Penelitian survei analitik dengan pendekatan cross-sectional ini dilakukan di ruangan rawat inap Rumah Sakit Bhayangkara tingkat II Medan pada bulan 18 Oktober-17 November 2018. Populasi dalam penelitian ini adalah pasien pengguna JKN pada bulan Januari-September 2018 sebanyak 1058 orang dengan estimasi menggunakan Analisis Rumus Trend Linier pada bulan Oktober sebanyak 132 orang. Kriteria subjek penelitian antara lain pasien yang mendapat rawat inap minimal 2 hari, pasien anak diwakilkan oleh orang tuanya dan tidak sedang terganggu jiwa dan ingatannya. Teknik pengambilan sampel menggunakan teknik purposive sampling yakni pengambilan sampel dengan cara menetapkan kriteria penelitian yang sesuai dengan tujuan penelitian sehingga diharapkan dapat menjawab permasalahan penelitian sebanyak 100 orang. Selanjutnya jumlah sampel tersebut dibagikan secara proporsional pada tiap-tiap ruangan pengguna Jaminan Kesehatan Nasional dengan proporsi ruangan Anggrek sebanyak 39 orang, ruangan Flamboyan sebanyak 13 orang, dan ruangan Mawar sebanyak 48 orang. Pengumpulan data dilakukan dengan menyebarkan kuesioner kepada responden, penelusuran dokumen/laporan dan studi kepustakaan.
Analisis data menggunakan uji Chi-square dan regresi logistik.

\section{Hasil}

Penelitian ini dilakukan pada bulan 18 Oktober-17 November 2018 di ruangan rawat inap Rumah Sakit Bhayangkara tingkat II Medan yang bertujuan untuk menganalisis kepuasan pasien rawat inap pengguna Jaminan Kesehatan Nasional di Rumah Sakit Bhayangkara Tingkat II Medan. Pasien dengan usia terbanyak adalah kelompok usia 26-35 tahun yaitu 28 orang $(28 \%)$. Jenis kelamin pasien terbanyak adalah perempuan yaitu 57 orang (57\%). Pekerjaan pasien terbanyak adalah Pegawai Negeri Sipil (PNS) yaitu 26 orang (26\%). Pendidikan terakhir pasien terbanyak adalah SMA yaitu 37 orang (37\%).

Distribusi frekuensi variabel tangibles tertinggi pada kategori baik sebanyak 65 orang (65\%), reliability katagori baik yaitu 54 orang (54\%), responsiveness kategori baik yaitu 61 orang (61\%), assurance kategori baik yaitu 60 orang $(60 \%)$, dan emphathy kategori baik yaitu 74 orang (74\%). Distribusi frekuensi untuk variabel kepuasan pasien terbanyak adalah puas sebesar 71 orang (71\%) dan kurang puas sebanyak 29 orang (29\%).

Tabel 1. Distribusi frekuensi responden pada 5 dimensi mutu pelayanan

\begin{tabular}{|c|c|c|}
\hline Variabel & $n=100$ & $\%$ \\
\hline \multicolumn{3}{|l|}{ Tangibles } \\
\hline Baik & 65 & 65 \\
\hline Tidak baik & 35 & 35 \\
\hline \multicolumn{3}{|l|}{ Reliability } \\
\hline Baik & 54 & 54 \\
\hline Tidak baik & 46 & 46 \\
\hline \multicolumn{3}{|l|}{ Responsiveness } \\
\hline Baik & 61 & 61 \\
\hline Tidak baik & 39 & 39 \\
\hline \multicolumn{3}{|l|}{ Assurance } \\
\hline Baik & 60 & 60 \\
\hline Tidak baik & 40 & 40 \\
\hline \multicolumn{3}{|l|}{ Emphathy } \\
\hline Baik & 74 & 74 \\
\hline Tidak baik & 26 & 26 \\
\hline \multicolumn{3}{|l|}{ Kepuasan Pasien } \\
\hline Puas & 71 & 71 \\
\hline Kurang puas & 29 & 29 \\
\hline
\end{tabular}


Hasil uji chi square menunjukkan variabel tangibles, reliability, responsiveness, assurance dan emphathy berhubungan dengan kepuasan pasien, masing-masing dengan nilai probabilitas yaitu 0,000 lebih kecil dari 0,05. Artinya kelima variabel yang diteliti berhubungan dengan kepuasan pasien. Pada tahap selanjutnya adalah analisis multivariat menggunakan uji regresi logistik berganda di mana semua variabel dapat disertakan.

Dari analisis multivariat diperoleh hasil berupa pengaruh yang signifikan variabel inde- penden secara bersama sama (simultan) terhadap variabel dependen atau kepuasan pasien dengan nilai $\mathrm{p}$ lebih kecil dari 0,05. Model akhir persamaan regresi logistik ganda untuk menentukan variabel yang sangat berpengaruh terhadap kepuasan pasien adalah dengan melihat nilai Exp (B) yang paling tinggi. Hasil uji didapatkan variabel reliability memiliki nilai Exp (B) yang paling tinggi sebesar 101.776 kali berpengaruh terhadap kepuasan pasien di ruang rawat inap Rumah Sakit Bhayangkara Tingkat II Medan dengan nilai $p<0,05$.

Tabel 2. Analisis multivariat

\begin{tabular}{lccc}
\hline Variabel & B & Nilai p & Exp (B) \\
\hline Tangibles & 3,886 & 0,002 & 48,700 \\
Reliability & 4,623 & 0,027 & 101,776 \\
Responsiveness & 3,213 & 0,022 & 24,847 \\
Assurance & 3,645 & 0,009 & 38,273 \\
Empathy & 3,296 & 0,016 & 27,009 \\
Constant & $-30,291$ & 0,003 & 0,000 \\
\hline
\end{tabular}

\section{Pembahasan}

Kepuasan adalah reaksi emosional terhadap kualitas pelayanan yang dirasakan dan kualitas pelayanan yang dirasakan merupakan pendapat menyeluruh atau sikap yang berhubungan dengan keutamaan pelayanan. Dengan kata lain kepuasan pelanggan adalah kualitas pelayanan yang dipandang dari kepentingan konsumen dalam hal ini adalah pasien. Pelayanan kesehatan yang berkualitas adalah pelayanan kesehatan yang dapat memuaskan setiap pemakai jasa pelayanan kesehatan sesuai dengan tingkat kepuasan rata-rata penduduk serta penyelenggaraannya sesuai dengan kode etik dan standar pelayanan profesi yang ada. ${ }^{13}$

Pada hasil analisis bivariat menunjukkan kepuasan pasien sebanyak 71 orang (71\%) mengatakan puas dibandingkan dengan kurang puas sebanyak 29 orang (29\%). Hal ini masih di bawah standar apabila merujuk pada standar pelayanan minimal di ruang rawat inap menurut Menteri Kesehatan Republik Indonesia No. 129/Menkes/SK/II2008 tentang Standar Pelayanan Minimal Rumah Sakit, standar pelayanan minimal di ruang rawat inap tentang kepuasan pasien adalah di atas atau sama dengan $90 \% .{ }^{14}$

Hasil survei yang dilakukan oleh BPJS tahun 2014 menunjukkan bahwa indeks nasi- onal kepuasan peserta adalah $81 \%$, sedangkan indeks nasional kepuasan faskes sebesar $75 \%$. Jika dibandingkan dengan sasaran pokok JKN 2014 yang ingin mencapai indeks kepuasan peserta sebesar $75 \%$ dan faskes sebesar $65 \%$. Hasil survei nasional ini menunjukkan bahwa BPJS Kesehatan di tahun pertama masa karyanya telah berhasil melampaui sasaran tersebut. Indeks kepuasan peserta rawat jalan adalah $81 \%$, sementara rawat inap $80 \%$. Artinya, kepuasan peserta rawat jalan sama tingginya dengan peserta rawat inap di rumah sakit. $^{7}$

Hasil survey BPJS Kesehatan mencatat, pada 2017 indeks kepuasan peserta sebanyak $79,5 \%$ dan untuk indeks kepuasan faskes sebesar $89,5 \%$. Sedangkan bila dibandingkan dengan indeks pada 2016, untuk kepuasan peserta sebesar $78,6 \%$ dan faskes $76,2 \%{ }^{15}$

Hasil penelitian ini berbeda dengan penelitian Alanri (2014) di Rumah Sakit Umum Daerah Kota Padangsidimpuan pada pasien pengguna jaminan kesehatan nasional dengan jumlah responden 298 orang. Hasil data analisisnya menunjukkan kepuasan pasien sebesar $38,3 \%$ (114 orang) dan tidak puas sebesar 61,7 $\%$ (184 orang). ${ }^{16}$

Kepuasan pasien tidak cukup dengan meningkatkan fasilitas lingkungan fisik, tetapi 
dalam upaya memberikan kepuasan kepada pelanggan/pasien adalah terutama dalam proses interaksi antara petugas dengan pasien dalam pelayanan kesehatan. Interaksi antara petugas dengan pasien merupakan hal yang sangat mendalam yang dirasakan pasien saat menerima pelayanan terutama saat mereka sangat memerlukan pertolongan. Proses interaksi ini dipengaruhi oleh perilaku petugas dalam melaksanakan pelayanan yaitu keramah tamaan, kecakapan, ketanggapan perhatian, komunikasi kecepatan melayani dan lain-lain. ${ }^{17}$

Tumbuhnya persaingan antar rumah sakit yang semakin ketat dan tajam, maka setiap rumah sakit dituntut untuk mempertinggi daya saing dengan berusaha memberikan kepuasan kepada semua pasiennya. Untuk itu harus diketahui faktor-faktor apa sajakah yang memengaruhi tingkat kepuasan pasien tersebut. Dan merupakan suatu hal yang sangat penting bagi kita untuk mengetahui apa yang pasien kita butuhkan untuk memenuhi kepuasan mereka terhadap pelayanan yang kita berikan. ${ }^{18}$

Hasil analisis bivariat menunjukkan variabel tangibles memiliki hubungan yang signifikan dengan kepuasan pasien rawat inap. Mayoritas responden dengan variabel Tangibles sebanyak 65 orang (65\%) mengatakan baik dibandingkan dengan tidak baik sebanyak 35 orang (35\%).

Bila dilihat berdasarkan item pertanyaan dalam kuesioner penelitian, mayoritas responden menjawab ruang tunggu rawat inap yang kurang luas dan nyaman, ruang kamar inap yang kurang bersih dan tenang. Kebersihan, ketenangan serta ruang tunggu bagi pasien merupakan hal yang harus diperhatikan karena dapat menimbulkan ketidakpuasan terhadap pelayanan yang diterimanya.

Hasil penelitian sesuai penelitian Alanri (2014) di Rumah Sakit Umum Daerah Kota Padangsidimpuan pada pasien pengguna jaminan kesehatan nasional dengan jumlah responden 298 orang. Hasil data analisisnya menunjukkan variabel tangibles mempunyai hubungan yang signifikan terhadap kepuasan pasien. ${ }^{15}$

Selanjutnya, penelitian serupa oleh Immas (2012) di Rumah Sakit Islam Kota Magelang. Hasil analisis datanya juga menunjukkan tangibles mempunyai hubungan dengan kepuasan pasien di rumah sakit tersebut. ${ }^{19}$

Ketidakpuasan pasien akan timbul karena pelayanan yang diterimanya terutama pemenuhan kebutuhan pasien dilihat dari segi fasilitas rumah sakit yang ada. Tangible yang baik akan memengaruhi persepsi pasien. Pada saat yang bersamaan aspek tangible ini juga merupakan salah satu sumber yang memengaruhi harapan pelanggan, karena tangible yang baik, maka harapan pelanggan menjadi lebih tinggi. ${ }^{20}$

Konsep dan teori yang mendukung dikemukakan oleh Lupiyoadi yang menyatakan bahwa kualitas pelayanan bukti fisik dari suatu pemasaran jasa, sangat ditentukan bukti fisik berupa penggunaan alat, ketersediaan perlengkapan yang terpenuhi dan kemampuan individu dari aspek pemasaran untuk memberikan suatu kualitas pelayanan yang dapat memuaskan konsumen. ${ }^{21}$

Hasil analisis bivariat menunjukkan variabel reliability memiliki hubungan yang signifikan dengan kepuasan pasien rawat inap. Mayoritas responden dengan variabel reliability hampir seimbang antara yang baik dan tidak baik sebanyak 54 orang (54\%) mengatakan baik dibandingkan dengan tidak baik sebanyak 46 orang (46\%).

Bila dilihat berdasarkan item pertanyaan dalam kuesioner penelitian, mayoritas responden menjawab karyawan yang kurang siap dalam melayani pasien, jadwal dokter visite yang kurang sesuai jadwal, serta kurangnya penjelasan yang dibutuhkan oleh pasien dan kurangnya waktu yang diberikan kepada pasien untuk berkonsultasi.

Hasil penelitian sesuai penelitian Aliah (2018) di Rumah Sakit Umum Daerah Haji Makasar pada pasien rawat inap dengan jumlah responden 250 orang, menunjukkan cukup pada variabel reliability sebanyak 133 orang $(53,2 \%)$ dan kurang sebanyak 117 orang $(46,8 \%)$. Analisis data menunjukkan variabel reliability mempunyai hubungan yang signifikan terhadap kepuasan pasien. ${ }^{22}$

Hasil penelitian berbeda dengan penelitian Alanri (2014) di Rumah Sakit Umum Daerah Kota Padangsidimpuan pada pasien pengguna jaminan kesehatan nasional dengan jumlah responden 298 orang, menunjukkan tidak baik pada variabel reliability sebanyak 
178 orang $(59,7 \%)$ dan baik sebanyak 120 orang (40.3\%). Hasil data analisisnya juga menunjukkan variabel reliability mempunyai hubungan yang signifikan terhadap kepuasan pasien. ${ }^{15}$

Pasien di ruang rawat inap Rumah Sakit Bhayangkara Tingkat II Medan yang menyatakan tidak puas disebabkan karyawan yang kurang siap dalam melayani pasien, jadwal dokter visite yang kurang sesuai jadwal, serta kurangnya penjelasan yang dibutuhkan oleh pasien dan kurangnya waktu yang diberikan kepada pasien untuk berkonsultasi. Petugas medis/paramedis merupakan orang yang berhubungan erat dengan pasien, dengan demikian kualitas petugas medis/paramedis sangat menentukan kepuasan pasien.

Sikap yang ditunjukkan dengan tingkah laku hendaknya sopan, sabar, ramah tamah, tidak ragu- ragu, penuh perhatian terhadap kebutuhan pasien, selalu bersedia memberi bantuan dan pertolongan, menemui pasien dengan sabar bagaimana pun keadaan, menciptakan situasi dan hubungan yang baik agar timbul kepercayaan pasien. Konsep dan teori yang mendukung dikemukakan oleh Parasuraman. Inti pelayanan reliability adalah setiap pegawai memiliki kemampuan yang handal, mengetahui mengenai seluk beluk prosedur kerja, mekanisme kerja, memperbaiki berbagai kekurangan atau penyimpangan yang tidak sesuai dengan prosedur kerja dan mampu menunjukkan, mengarahkan, dan memberikan arahan yang benar kepada setiap bentuk pelayanan yang belum dimengerti oleh masyarakat, sehingga memberi dampak positif atas pelayanan tersebut yaitu pegawai memahami, menguasai, handal, mandiri dan profesional atas uraian kerja yang ditekuninya. ${ }^{20}$

Hasil analisis bivariat menunjukkan variabel responsiveness memiliki hubungan yang signifikan dengan kepuasan pasien rawat inap. Mayoritas responden dengan variabel responsiveness sebanyak 61 orang (61\%) mengatakan baik dibandingkan dengan tidak baik sebanyak 39 orang (39\%). Bila dilihat berdasarkan item pertanyaan dalam kuesioner penelitian, mayoritas responden menjawab kurangnya karyawan yang mampu memberikan penjelasan dan pelayanan cepat serta membuat pasien terlalu lama menunggu.
Penelitian Aliah (2018) di Rumah Sakit Umum Daerah Haji Makasar pada pasien rawat inap dengan jumlah responden 250 orang, menunjukkan cukup pada variabel responsiveness sebanyak 135 orang (54\%) dan kurang sebanyak 115 orang (46\%). Hasil data analisisnya juga menunjukkan variabel responsiveness mempunyai hubungan yang signifikan terhadap kepuasan pasien. ${ }^{22}$ Selanjutnya penelitian Purnama (2010) menyimpulkan bahwa kecepatan pelayanan yang diberikan memiliki hubungan yang signifikan terhadap kepuasan pasien. Kecepatan dalam pemberian pelayanan berupa pemenuhan kebutuhan yang utama seperti dalam menginformasi apa penyakit dan bagaimana menangani penyakit tersebut serta kecepatan dalam menerima dan memeriksa pasien. ${ }^{23}$

Pasien JKN di ruang rawat inap Rumah Sakit Bhayangkara Tingkat II Medan yang menyatakan tidak puas terhadap pelayanan disebabkan kurangnya karyawan yang mampu memberikan penjelasan dan pelayanan cepat serta membuat pasien terlalu lama menunggu. Di bagian penerimaan pasien juga menunggu lama. Proses pendaftaran sampai masuk ke ruangan juga memakan waktu yang lama. Bagian penerimaan atau informasi merupakan wajah dari rumah sakit di mana pasien akan mendapatkan kesan pertama tentang rumah sakit. Agar kesan pertama tersebut mendapat nilai yang baik maka sebaiknya petugas yang melayani bersikap ramah, sopan, penuh pengertian, terampil, cepat dan informatif.

Pada prinsipnya, inti dari bentuk pelayanan yang diterapkan dalam suatu instansi atau aktivitas pelayanan kerja yaitu memberikan pelayanan sesuai dengan tingkat ketanggapan atas permasalahan pelayanan yang diberikan. Kurangnya ketanggapan dari orang yang menerima pelayanan, karena bentuk pelayanan tersebut baru dihadapi pertama kali, sehingga memerlukan banyak informasi mengenai syarat dan prosedur pelayanan yang cepat, mudah dan lancar, sehingga pihak petugas atau pemberi pelayanan seyogyanya menuntun orang yang dilayani sesuai dengan penjelasan-penjelasan yang mendetail, singkat dan jelas yang tidak menimbulkan berbagai pertanyaan atau hal- hal yang menimbulkan keluh kesah dari orang yang mendapat pelayanan. 
Apabila hal ini dilakukan dengan baik, berarti petugas tersebut memiliki kemampuan daya tanggap terhadap pelayanan yang diberikan yang menjadi penyebab terjadinya pelayanan yang optimal sesuai dengan tingkat kecepatan, kemudahan dan kelancaran dari suatu pelayanan yang ditangani oleh petugas. ${ }^{20}$

Hasil analisis bivariat menunjukkan variabel assurance memiliki hubungan yang signifikan dengan kepuasan pasien rawat inap. Mayoritas responden dengan variabel assurance sebanyak 60 orang (60\%) mengatakan baik dibandingkan dengan tidak baik sebanyak 40 orang (40\%). Bila dilihat berdasarkan item pertanyaan dalam kuesioner penelitian, mayoritas responden menjawab kurangnya karyawan yang sopan dan ramah kepada pasien.

Hasil penelitian ini sejalan dengan penelitian Aliah (2018) di Rumah Sakit Umum Daerah Haji Makasar pada pasien rawat inap dengan jumlah responden 250 orang, menunjukkan cukup pada variabel assurance sebanyak 136 orang $(54,4 \%)$ dan kurang sebanyak 114 orang $(45,6 \%)$. Hasil data analisisnya juga menunjukkan variabel assurance mempunyai hubungan yang signifikan terhadap kepuasan pasien. ${ }^{22}$

Pasien JKN di ruang rawat inap Rumah Sakit Bhayangkara Tingkat II Medan yang menyatakan tidak puas terhadap pelayanan karena sikap paramedis yang terkesan arogan sehingga nampak kurang ramah, kurang mengerti perasaan, dan kurang menaruh perhatian sepenuhnya. Perawat cenderung tidak ramah dalam menjawab pertanyaan pasien/ keluarga, tidak menjelaskan terlebih dahulu secara rinci prosedur setiap tindakan yang akan dilakukan kepada pasien.

Menurut Margaretha (2003), suatu organisasi kerja sangat memerlukan adanya kepercayaan yang diyakini sehingga organisasi tersebut mampu memberikan kepuasan dalam pelayanan, mampu menunjukkan komitmen kerja yang tinggi, mampu memberikan kepastian atas pelayanan sesuai dengan perilaku yang ditunjukkan. ${ }^{24}$

Hasil analisis bivariat menunjukkan variabel empathy memiliki hubungan yang signifikan dengan kepuasan pasien rawat inap. Mayoritas responden dengan variabel empathy sebanyak 74 orang (74\%) mengatakan baik dibandingkan dengan tidak baik sebanyak 26 orang (26\%). Bila dilihat berdasarkan item pertanyaan dalam kuesioner penelitian, mayoritas responden menjawab kurangnya waktu yang cukup bagi keluarga pasien untuk berkonsultasi.

Penelitian Aliah (2018) di Rumah Sakit Umum Daerah Haji Makasar pada pasien rawat inap dengan jumlah responden 250 orang, menunjukkan cukup pada variabel empathy sebanyak 148 orang $(59,2 \%)$ dan kurang sebanyak 102 orang $(40,8 \%)$. Hasil data analisisnya juga menunjukkan variabel empathy mempunyai hubungan yang signifikan terhadap kepuasan pasien. ${ }^{22}$

Penelitian serupa lainnya oleh Hendrawati (2009) menyimpulkan bahwa perawat yang memiliki emphaty yang baik maka akan menimbulkan rasa puas kepada pasien, sehingga pasien akan menyimpulkan bahwa pelayanan yang diterimanya baik. Perhatian merupakan indikator yang dapat menimbulkan kepuasan dalam diri seseorang. ${ }^{25}$

Perawat Rumah Sakit Bhayangkara Tingkat II Medan kurang memiliki sikap emphaty kepada pasien. Pasien JKN mengeluhkan tentang sikap perawat yang kurang memperhatikan kebutuhan pasien. Perawat tidak tahu apa yang dibutuhkan pasien kecuali diminta oleh keluarga pasien. Perawat enggan untuk diajak berkomunikasi tentang kondisi pasien, padahal keluarga terkadang bingung harus bertanya kepada siapa.

Hasil analisis multivariat bahwa tangibles, reliability, responsiveness, assurance dan emphaty memiliki pengaruh terhadap kepuasan pasien ruang rawat inap. Selain itu, terdapat variabel yang sangat dominan memengaruhinya yakni reliability karena memiliki nilai Exp (B) sebesar 101.776. Dalam penelitian ini, variabel yang paling dominan adalah reliability. Berbanding lurus dengan kepuasan, bila reliability yang diberikan oleh tenaga kesehatan pelayanan rawat inap baik, maka kepuasan pasien juga akan semakin baik.

Sekitar 60\% dari keluhan konsumen berasal dari ketidakpuasan terhadap perusahaan yang berhubungan dengan dimensi ini. Konsumen mengeluh karena perusahaan tidak menepati janjinya atau melakukan kesalahan dalam memberikan pelayanan. Dalam industri jasa, perusahaan bergantung pada manusia yang memang susah konsisten. ${ }^{26}$

Menurut Lupiyoadi (2013), tangibles adalah suatu pelayanan tidak bisa dilihat, tidak 
bisa dicium dan tidak bisa diraba. Maka aspek tangible menjadi penting sebagai ukuran terhadap pelayanan. Pelanggan akan menggunakan indra penglihatan untuk menilai suatu kualitas pelayanan atribut dari dimensi tangible meliputi gedung, peralatan, seragam, dan penampilan fisik para karyawan yang melayani pelanggannya. ${ }^{21}$

Kepuasan peserta BPJS Kesehatan yang datang ke RS Pemerintah (80\%) lebih rendah dari RS Swasta (83\%). Dimensi tangible (seperti fasilitas rumah sakit dan peralatan) serta dimensi responsiveness (kecepat-tanggapan dalam melayani) merupakan titik lemah dari RS pemerintah jika dibandingkan RS Swasta, yang pada akhirnya memengaruhi tingkat kepuasan peserta. $^{7}$

\section{Kesimpulan}

Penelitian ini menyimpulkan adanya hubungan antara variabel tangibles, reliability, responsiveness, assurance dan emphathy berhubungan dengan kepuasan pasien, masing-masing dengan nilai probabilitas $0,000(p<0,05)$. Variabel reliability merupakan yang paling dominan dalam memengaruhi kepuasan pasien di ruang rawat inap Rumah Sakit Bhayangkara Tingkat II Medan $(\operatorname{Exp}(B)=101.776)$.

\section{Referensi}

1. Azwar A. Menjaga Mutu Pelayanan Kesehatan. Jakarta: Pustaka Sinar Harapan; 2007.

2. Kementerian RI. Rencana strategi Kementrian kesehatan. Direktorat Jenderal Bina Pelayanan Medik. Jakarta: Kemenkes Rl; 2015.

3. Trisnantoro L. Memahami Penggunaan Ilmu Ekonomi dalam Manajemen Rumah Sakit. Yogyakarta: Penerbit Gajah Mada University Press; 2015.

4. Trisnawati K. Analisis kepuasan pasien rawat jalan PUS Pada Masa Pelaksanaan Askes Dan JKN Di RSUP Dr.sardjito. Tesis, Yogyakarta: Universitas Gajah Mada; 2015.

5. Kotler P., dan Armstrong G. Prinsip Prinsip Pemasaran. Edisi 13. Jilid 1. Jakarta: Erlangga; 2012.

6. Khariza H.A. Program Jaminan Kesehatan Nasional: Studi Deskriptif Tentang FaktorFaktor Yang Dapat Mempengaruhi
Keberhasilan Implementasi Program Jaminan Kesehatan Nasional Di Rumah Sakit Jiwa Menur Surabaya. Jurnal Kebijakan Manajemen Publik, 2015, 3 (1): 1-7.

7. BPJS Kesehatan. Panduan Layanan Bagi Peserta BPJS Kesehatan. Jakarta: BPJS Kesehatan; 2015.

8. Fadillah M. Pengaruh Kualitas Pelayanan Terhadap Kepuasan Peserta Bpjs Di Rumah Sakit Umum Daerah Langsa Tahun 2017. Skripsi FKM. Medan: Universitas Sumatera Utara; 2018.

9. Pertiwi A. Analisis Perbedaan Kualitas Pelayanan Pada Pasien Bpjs Dan Pasien Umum Terhadap Kepuasan Pasien Di Rawat Jalan RSUD Kota Surakarta. Jurnal Ekonomi Manajemen Sumber Daya, 2016, 18 (2).

10. Rumah Sakit Bhayangkara Tingkat II. Profil Rumah Sakit Bhayangkara Tingkat II. Medan: Rumah Sakit Bhayangkara Tingkat II; 2018.

11. Rumah Sakit Bhayangkara Tingkat II. Data Pelayanan Medik Rumah Sakit Bhayangkara Tingkat II. Medan: Rumah Sakit Bhayangkara Tingkat II; 2018.

12. Rumah Sakit Bhayangkara Tingkat II. Data Rekam Medik Rumah Sakit Bhayangkara Tingkat II. Medan: Rumah Sakit Bhayangkara Tingkat II; 2018.

13. Tjiptono F. dan Chandra. Service, Quality and Satisfaction, 3rd ed. Yogyakarta: Penerbit Andi; 2011.

14. Departemen Kesehatan RI. Keputusan Menteri Kesehatan Republik Indonesia Nomor 129/MENKES/SK/II/2008 tentang Standar Pelayanan Minimal Rumah Sakit. Jakarta: Depkes RI; 2008.

15. BPJS Kesehatan. Survei kepuasan Peserta dan Fasilitas Kesehatan BPJS Kesehatan tahun 2017. Jakarta: BPJS Kesehatan; 2017.

16. Alanri F. Analisis Mutu Pelayanan Terhadap Kepuasan Pasien Jaminan Kesehatan Nasional Di Rumah Sakit Umum Daerah Kota Padangsidimpuan. Tesis FKM. Medan: Universitas Sumatera Utara; 2015.

17. Wijono D. Manajemen Mutu Pelayanan Kesehatan, Teori, Strategi dan Aplikasi, Volume 2. Surabaya: Airlangga University Press; 2015. 
18. Wijayanti. Analisa Faktor Penentu Tingkat Kepuasan Pasien Di Rumah Sakit PKU Muhammadiyah Bantul. Skripsi. Fakultas Kedokteran Universitas Islam Indonesia 2 Departemen Ilmu Kesehatan Masyarakat FK UII JKKI-Jurnal Kedokteran dan Kesehatan Indonesia, 2008.

19. Immas Y. Pengaruh Kualitas Pelayanan Terhadap Kepuasan Pasien Di Rumah Sakit Islam Kota Magelang. Skripsi. Surakarta: Universitas Sebelas Mei Surakarta; 2012.

20. Parasuraman A.V. Delivering Quality Service. Diterjemahkan oleh Sutanto. New York: The Free Press, New York; 2001.

21. Lupiyoadi, Rambat. Manajemen Pemasaran Jasa. Jakarta: Salemba Empat; 2013.

22. Aliah N. Analisis Kepuasan Pasien Rawat Inap Dirumah Sakit Pemerintah (Rsud Haji Makassar) "Analysis Of Patient Satisfaction Of Inpatient At Public Hospital (RSUHaji Makassar)". Tesis. Makassar: Universitas Hasanuddin; 2018.

23. Purnama N. Manajemen Kualitas Edisi Pertama. Yogyakarta: EKONISIA; 2006.

24. Margaretha F. Teori dan Aplikasi Manajemen Keuangan Investasi dan Sumber Dana Jangka Pendek. Jakarta: Grasindo Gramedia Widiasarana Indonesia; 2003.

25. Hendrawati, Kristina K. Hubungan Komunikasi Perawat dengan Kualitas Pelayanan Keperawatan di Ruang Kelas 3 Rumah Sakit Baptis Kediri. Skripsi Keperawatan Strata I. Sekolah Tinggi IImu Kesehatan Rumah Sakit Baptis Kediri; 2009.

26. Irawan H. 10 Prinsip Kepuasan Pelanggan. Paradigma Baru Merebut Hati Pelanggan Untuk Memenangkan Persaingan. Jakarta: Gramedia; 2009. 